\title{
Estudo da contabilização dos tributos astecas sob a ótica da nova história da contabilidade*
}

\author{
Estudio de la contabilización de los tributos aztecas bajo la óptica de la nueva historia de la contabilidad Study of \\ the accounting of Aztec tributes from the perspective of the new history of accounting
}

Paulo Schmidt ${ }^{\text {a }}$

Universidade Federal do Rio Grande do Sul (UFRGS),

DOI: https://doi.org/10.11144/Javeriana.cc21.ecta

Brasil

pschmidt@ufrgs.br

ORCID: https://orcid.org/0000-0002-7341-1316

Recepção: 27 Junho 2019

Aprovação: 21 Julho 2020

José Luiz dos Santos

União das Faculdades Integradas de Negócios, Brasil

ORCID: https://orcid.org/0000-0002-1202-9252

\section{Resumo:}

O estudo examina a Matrícula de Tributos como elemento de contabilização tributária asteca, dentro da dimensão da Nova História da Contabilidade (NHC), com abordagem de pesquisa na História da Cultura Material. A pesquisa classifica-se como histórica qualitativa, com procedimentos de análise bibliográfica e documental, utilizando documentos primários como a Matrícula de Tributos e o Códice Mendoza. Identificou-se que a Matrícula de Tributos foi um objeto material criado para impor uma ordem tributária incontestável, refletidora do poder divino e hereditário de Montezuma. Esse objeto serviu para a criação, pelos hispânicos, do Códice Mendoza, que seria utilizado para apresentar as principais características da sociedade asteca ao imperador espanhol. A análise da Matrícula de Tributos e do Códice Mendoza permitiu identificar os inter-relacionamentos entre culturas, destacando a Matrícula como elemento tradutor do poder imperial, tanto pelo aspecto arrecadatório, como hierárquico da sociedade asteca. O estudo desvendou o cenário sociopolítico que originou as práticas contábeis tributárias, não focando na técnica do registro, mas examinando a prática em que a Contabilidade estava inserida na sociedade asteca. A partir desse estudo, é possível vislumbrar a análise de outros objetos da cultura material, como os Quipus incas e os códices maias, seguindo os conceitos da NHC.

Código JEL: N46

Palavras-chave: Matrícula de Tributos, Códice Mendoza, Tributos Astecas, Contabilização de Tributos.

\section{Resumen:}

El estudio examina la Matrícula de Tributos como elemento de contabilización tributaria azteca, dentro de la dimensión de la Nueva Historia de la Contabilidad (NHC), con abordaje de investigación en la Historia de la Cultura Material. La investigación se clasifica como histórica cualitativa, con procedimientos de análisis bibliográfico y documental, utilizando documentos primarios como la Matrícula de Tributos y el Códice Mendoza. Se identificó que la Matrícula de Tributos fue un objeto material creado para imponer un orden tributario indiscutible, que reflejara el poder divino y hereditario de Moctezuma. Este objeto sirvió para la creación, por parte de los hispanos, del Códice Mendoza, que sería utilizado para presentar las principales características de la sociedad azteca al emperador español. El análisis de la Matrícula de Tributos y el Códice Mendoza permitió identificar las interrelaciones entre culturas, destacando la Matrícula como elemento traductor del poder imperial, tanto para el aspecto recaudatorio, como jerarquizador de la sociedad azteca. El estudio reveló el escenario sociopolítico que dio origen a las prácticas contables tributarias, sin centrarse en la técnica del registro, sino examinando la práctica en la que la Contabilidad se insertaba en la sociedad azteca. A partir de este estudio es posible vislumbrar el análisis de otros objetos de la cultura material, como los Quipus incas y los códices mayas, siguiendo los conceptos de la NHC.

Código JEL: N46

Palabras clave: Matrícula de Tributos, Códice Mendoza, Tributos Aztecas, Contabilización de Tributos.

\section{Abstract:}

The study examines the Matrícula de Tributos (Tribute roll) as an element of Aztec tax accounting, within the dimension of the New Accounting History (NAH), with a research approach in the History of Material Culture. The research is classified as a

\section{Autor notes}

\footnotetext{
a Autor de correspondencia. Correo electrónico: pschmidt@ufrgs.br
} 
qualitative historical, with bibliographical and documentary analysis procedures, using primary documents such as the Matrícula de Tributos and the Codex Mendoza. It was identified that the Matrícula de Tributos was a material object created to impose an undisputed tax order, reflecting Montezuma's divine and hereditary power. This object served for the creation, by the Hispanics, of the Codex Mendoza, which would be used to present the main characteristics of the Aztec society to the Spanish emperor. The analysis of the Matrícula de Tributos and the Codex Mendoza made it possible to identify the interrelationships between cultures, highlighting the Matrícula as a translator element of imperial power, both for the collection and hierarchical aspect of Aztec society. The study uncovered the socio-political scenario that gave rise to tax accounting practices, not focusing on the registration technique, but examining the practice in which Accounting was embedded in Aztec society. From this study, it is possible to glimpse the analysis of other objects of the material culture, such as the Inca Quipus and the Mayan codices, following the concepts of the NAH.

JEL Code: N46

Keywords: Matrícula de Tributos, Codex Mendoza, Aztec tributes, Accounting for Taxes.

\section{Introdução}

Estudar a história de uma civilização implica a percepção de que os eventos passados ocorreram dentro de um fluxo de eventos que é contínuo e infinito, ao passo que a análise do legado de uma civilização, normalmente, se dá de forma descontínua e muitas vezes desconexa (Guarinello, 2003).

O estudo da história de um povo antigo se insere em um contexto em que se busca contribuir para o entendimento da realidade atual, buscando vincular o desenvolvimento do passado com algumas ferramentas utilizadas no cotidiano do homem moderno.

Uma das últimas regiões povoada pelos antigos habitantes da terra foi o continente americano, quando os povos passaram a ocupar a extensão territorial do continente, desenvolvendo uma grande variedade de culturas adaptadas ao ambiente específico de cada tribo (Fagundes, 2007).

Para Bedoya-Salazar et al. (2017) existem evidências arqueológicas de comunidades no continente americano ligadas ao cultivo do milho há cerca de 9000 anos, especialmente na Mesoamérica, tendo destaque nessa região as culturas pré-colombianas de Olmeca, que se desenvolveram ao longo do Golfo do México (1200-500 a.C.); a cultura Maya (1100 a.C.-1000 d.C.) e Zapotec (500 a.C.- 900 d.C.), que surgiram no sul do México e na Guatemala; e as culturas Teotihuacan (1-600 d.C.), Toltec (800-1100 d.C.) e Astecas (1200-1520 d.C.), que surgiram nas terras altas do México Central.

Dessas comunidades, os astecas, também conhecidos como mexicanos ou mexicas, dominavam a maior parte do território mexicano comandados por Montezuma II, quando os conquistadores espanhóis aportaram na região em 1519, tendo como capital a cidade de Tenochtitlán, atual Cidade do México (Campos \& Claro, 2013). Graças ao caráter guerreiro dessa civilização, os astecas formaram um imenso império com grandes cidades, mercados, palácios, templos e uma complexa organização política e social com grandes riquezas, que cobriu toda a zona meridional do atual território mexicano. Na época da conquista espanhola, o território asteca era composto por 38 províncias (funcionavam normalmente como cidades-estados), que financiavam o poder central do império com o recolhimento de impostos (Melo, 2013).

De um modo geral, quando as cidades-estados assumiam os gastos com as tropas militares do imperador não pagavam tributos, porém as demais cidades, ou pagavam tributos de uma a quatro vezes por ano, dependendo do tipo de mercadorias e produtos que produziam, ou pelo menos, estavam sujeitas ao envio de donativos de forma voluntária para agradar ao imperador (Soustelle, 2002).

O império asteca mantinha um processo sistematizado de contabilização de toda movimentação dos tributos imperiais em documentos denominados de códices. "Os códices astecas são documentos raros preservados pelos próprios autores que os esconderam, tal sua importância na organização simbólica da vida coletiva" (Anthônio, 2017, p. 118). Dentre os códices astecas, o chamado Matrícula de Tributos era um dos mais reconhecidos manuscritos utilizados para registro e controle da movimentação de tributos do Império (Soustelle, 2002). 
A Matrícula de Tributos foi um dos principais documentos utilizados pelos astecas para registro da movimentação tributária das cidades imperiais, e servia como instrumento para adicionar, excluir ou registrar alterações nas dívidas de cada comunidade do Império Asteca. Segundo Rosado (2007a, p. 33), "era um documento oficial na administração imperial de Tenochtitlán e que, como tal, deveria estar livre de erros. Seu objetivo era registrar e dar conta do tributo devido ao império mexica”. Normalmente, era produzida em lâminas de papel amate (uma espécie de papiro mexicano), com um conjunto de páginas individuais, pintadas de um lado e posteriormente coladas, formando uma espécie de livro (Rosado, 2007a). Esse livro, considerado um dos documentos mais importantes da organização imperial, retratava a relação entre as províncias e a capital do Império Asteca Tenochtitlán.

A Matrícula de Tributos foi posteriormente transcrita como uma seção do denominado Códice Mendoza, criado após a invasão espanhola ao império asteca (Rosado, 2007a; Rojas, 1995). O Códice Mendoza também foi uma espécie de manuscrito pictórico, pintado com figuras coloridas, e tinha o objetivo de registrar e transmitir informações para o Imperador da Espanha sobre a história asteca, suas práticas tributárias e sua vida social (Ronco \& Martorelli, 2008).

Pesquisas históricas sobre a Matrícula de Tributos, e sobre sua posterior transcrição como uma parte do Códice Mendoza, estão focadas em análises antropológicas e codicológicas, no exame dos pictogramas e das formas gráficas, na análise da preservação do patrimônio cultural sob a perspectiva mitológica e sociológica, como os trabalhos de Berdan e Anawalt (1997), Valle (2017) e Salazar e López (2015). Além desses focos de pesquisa, existem estudos direcionados para a análise sobre os aspectos econômico e tributário, como os de Berdan (1976), Smith (2015), Rosado (2007a), Rojas e Batalla (2008).

Conforme destaca Rojas (1995), a maioria das interpretações históricas do sistema tributário asteca tem origem nas análises de seus códices e dos códices dos conquistadores espanhóis, embora, mesmo com uma grande quantidade de estudos já realizados, ainda permaneçam pontos obscuros que necessitam ser clarificados como a frequência do pagamento de tributos, a questão de se as cobranças eram realizadas com cargas totais ou por unidades e se os registros dos tributos eram anuais, independente da periodicidade do pagamento.

Dentro dessa conjuntura de análise histórica de objetos materiais, como são a Matrícula de Tributos e sua posterior transferência para o Códice Mendoza, vislumbraram ao final do século XX mudanças significativas na forma de olhar o mundo passado, em particular a partir do surgimento da denominada Nova História da Contabilidade (NHC), dentro do contexto geral da Nova História. Burke (1992) e Chartier (2010) destacam o fato de que pesquisas históricas passaram a valorizar mais os fatos passados, buscando novas abordagens e novos diálogos com outras áreas do conhecimento humano, investigando trajetórias de pessoas e acontecimentos comuns, não somente de líderes mundiais e de grandes transformações sociais, e procurando múltiplas visões para uma maior pluralidade cultural.

Para Barros (2011), essas mudanças na trajetória dos estudos históricos desencadearam novas perspectivas de análise, levando em consideração:

- Dimensões históricas: determinam qual o enfoque da pesquisa histórica, por exemplo: na História Social, Nova História Cultural, História Econômica, etc.;

- Abordagens históricas: definem os métodos e modos de fazer da história, os tipos e as formas de tratamento das fontes de pesquisa do estudo histórico, tais como: análise arqueológica, estudos históricos da Cultura Material, de discursos, Micro-História, etc.;

- Domínios históricos: determinam o campo temático da pesquisa histórica e direcionam para as áreas de concentração do tema explorado, podendo estar relacionado com ambientes sociais ou objetos, como a história da vida privada, da vida rural, do Direito, da Administração, da Contabilidade, etc.

Assim, dentro desse novo contexto de análise histórica e a partir de uma análise fundamentada na NHC, este estudo busca responder como os astecas contabilizavam seus tributos. Para isso, objetivou-se examinar 
a Matrícula de Tributos e sua posterior transcrição para o Códice Mendoza, dentro da dimensão de estudo da NHC, com uma abordagem de pesquisa na História da Cultura Material e focando no domínio histórico desse objeto de controle contábil dos tributos astecas.

O estudo, considerando que apresenta e discute vários documentos de fontes primárias da cultura Asteca que foram sub-representados em outros estudos, busca avançar na análise contábil sob a perspectiva histórica, particularmente com relação à forma como esse povo controlava contabilmente seus tributos e como esses controles deram origem a um documento que serviu de ferramenta para gerar informaçóes sobre a vida asteca para o poder central espanhol. De tal maneira, os resultados alcançados visam contribuir para que pesquisadores da Contabilidade possam desvendar o funcionamento de um complexo sistema contábiltributário desenvolvido pelos astecas.

A investigação está delimitada sob a ótica da Nova História Cultural na Matrícula de Tributos, e de forma complementar na segunda parte do Códice Mendoza por transcrevê-la quase a integralidade, como objeto de contabilização de tributos, com foco na NHC. As demais análises históricas possíveis não são tema dessa pesquisa.

\section{Procedimentos metodológicos}

Do ponto de vista metodológico, essa pesquisa se caracteriza como histórica e documental. Assim, tem como pressuposto de análise a compreensão dos fenômenos históricos através dos acontecimentos passados (Maia et al., 2011). Neste contexto e dentro da perspectiva da Nova História Cultural, e de forma específica da NHC, adotou-se um enfoque sistemático no processo de coleta, organização e avaliação crítica de dados relacionados à utilização pelos astecas da Matrícula de Tributos com o propósito de registro e controle destes, bem como à transcrição da mesma para o Códice Mendoza.

No que se refere à abordagem do problema, essa pesquisa se classifica como qualitativa, atendendo que se buscou apreender o fenômeno em análise a partir da perspectiva dos atores nele implicados e dos pontos de vista mais relevantes, seguindo as concepções apresentadas por Padilha e Borenstein (2005).

Com relação aos procedimentos técnicos para realizar a pesquisa, foram adotados processos de análise documental e bibliográfica. A análise concentrou-se em dois documentos básicos: a Matrícula de Tributos e a segunda parte do Códice Mendoza, assim como em pesquisas realizadas sobre essas ferramentas, sobretudo no que se refere à importância da Matrícula como elemento de registro e controle do processo tributário asteca. A operacionalização das pesquisas documentais e bibliográficas ocorreu por meio da análise dos mais variados documentos, como fotografias, acervo de museus, documentos primários digitalizados e hipertextos, com destaque para a Matrícula de Tributos, disponibilizada digitalmente pela Biblioteca Digital Mundial da Organização das Nações Unidas, e para o Códice Mendoza, através da hipermídia disponível na página da Bodleian Libraries da Universidade de Oxford.

Os procedimentos de leitura dos documentos e bibliografias utilizados na pesquisa partiram de uma préleitura, o que corresponde a uma fase preliminar de uma análise informativa; após, uma leitura seletiva, com a qual se selecionaram documentos e bibliografias pertinentes com a pesquisa; a seguir, uma leitura crítica e reflexiva, onde buscou-se identificar os aspectos mais relevantes dos documentos e bibliografias analisadas; e, por fim, uma leitura interpretativa para que essa análise permitisse contribuir diretamente no atingimento dos objetivos propostos pela pesquisa.

Esta pesquisa se caracteriza como descritiva, dado que busca a descrição das principais características de determinada população ou fenômeno, e ainda, o estabelecimento de relações entre as variáveis (Silva, 2010). 


\section{O uso dos códices na cultura asteca}

O intuito dessa seção é apresentar como o império asteca se desenvolveu e de que forma os códices eram utilizados dentro da cultura mexica.

\section{O Império Asteca}

O império asteca foi criado no século XIII a partir da aliança de três centros hegemônicos da região: Tenochtitlán, Texcoco e Tlacopan, e passou a incorporar novos territórios, chegando a 38 províncias na época da invasão espanhola, em 1519 (Petroni, 2004). A figura 1 apresenta os símbolos (glifos) de cada uma das três regiões que formavam a Tríplice Aliança.

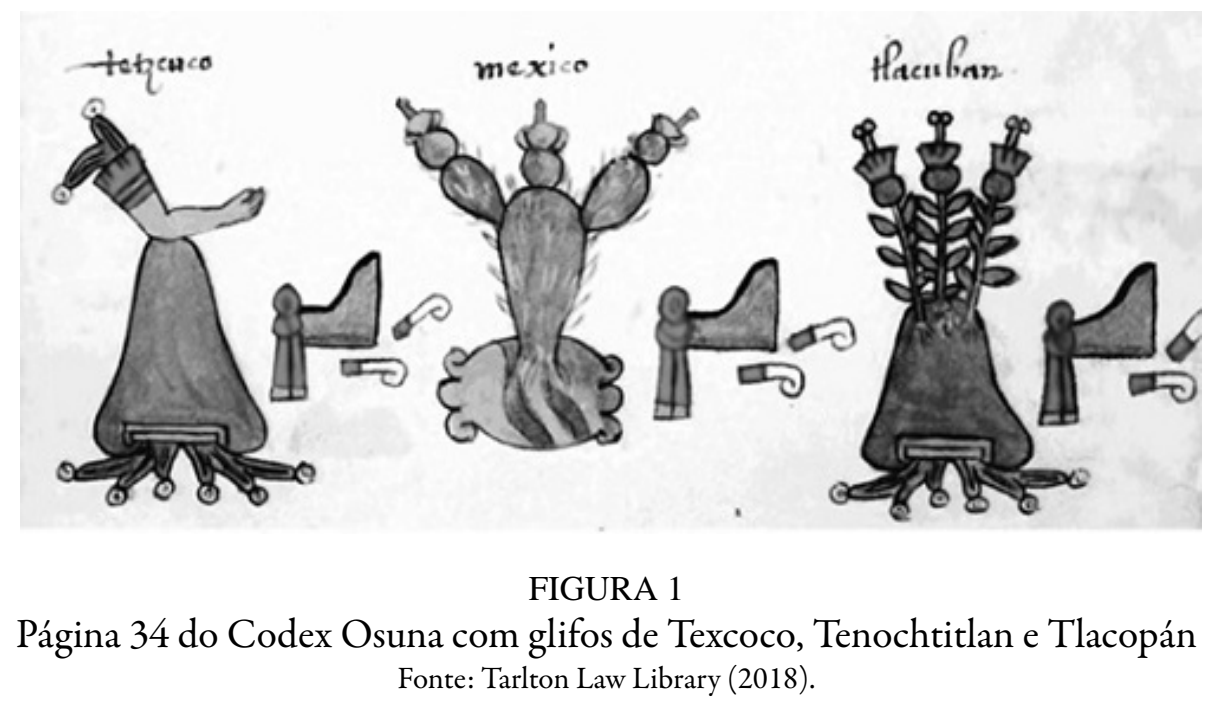

A sociedade era dominada por uma classe social nobre e hereditária, formada por algo em torno de $5 \% \mathrm{da}$ população, que administrava o império e controlava as terras e os restantes $95 \%$ da população.

Para a Tarlton Law Library (2018), o império asteca tinha nos tributos a sua principal fonte de renda. Todas as regiões conquistadas tinham a obrigação de pagarem impostos, assim como todos os cidadãos astecas, com exceção dos religiosos, nobres, menores, órfãos, inválidos e mendigos, sendo que o não pagamento pelos devedores poderia gerar penalidades para as pessoas como a escravidão ou o confisco dos bens, bem como severas punições para as regiões rebeldes que não cumprissem suas obrigações tributárias, inclusive ações militares advindas do poder central.

As contribuções pagas aos cofres imperiais eram recolhidas em intervalos de 80 dias, 6 ou 12 meses, dependendo do tipo de atividade do devedor e da distância que os coletores de impostos tinham que percorrer, tendo em consideração que eram os responsáveis pelo recebimento, coleta e transporte dos recursos arrecadados (Tarlton Law Library, 2018).

Os tributos imperiais eram registrados em livros, chamados de códices, que ficavam armazenados nas denominadas casas dos livros imperiais, designadas na linguagem asteca como amoxcalli, conforme Tello (2012).

\section{Os Códices Astecas}

Segundo Ronco e Martorelli (2008), os códices astecas eram feitos com lâminas de papel amate, fabricadas da cortiça de figueira, de folhas de maguey aplanadas, eventualmente de pele de veado tratadas com uma capa de gesso ou cal, ou de panos de algodão, unidas como se fossem uma sanfona e protegidas por capas de madeiras. 
Esses códices representam documentos pictoriais da vida coletiva do povo asteca, pintados com várias cores, demonstrando um sofisticado domínio técnico desse povo na confecção de tintas utilizadas na pintura dos livros (Anthônio, 2017).

A invasão espanhola causou o fim do império asteca e de seus principais vestígios culturais (Santos, 2013). Apenas nove códices astecas pré-hispânicos se salvaram da destruição depois da conquista espanhola: "o Borbónico, a Matrícula de Tributos, a Tira de la Peregrinación, e os seis que formam o Grupo Borgia: Borgia, Cospi, Fjervary-Mayer, Laud, Pintura 20 da Coleção Goupil-Aubin e o Vaticano B3773 da cultura PueblaTaxcala”. (Ronco \& Martorelli, 2008, p. 120).

Desses códices astecas pré-hispânicos, o Matrícula de Tributos era o único dedicado ao registro das tributações aplicadas no império mexica. Para Rosado (2007a, p. 31), "provavelmente foi pintado durante a última década do governo de Montezuma II, embora algumas páginas possam ter sido produzidas anteriormente". Na produção desse códice devem ter trabalhado pelo menos seis escribas, embora o conteúdo foi transcrito por um único artista, ao redor de 1542, na segunda parte do Códice Mendoza (Rosado, 2007a).

\section{Sistema tributário asteca e o uso da Matrícula de Tributos e do Códice Mendoza}

Essa seção apresenta como os astecas gerenciavam seu sistema tributário, especialmente com o uso da Matrícula de Tributos e como essa ferramenta serviu de espelho para a criação do documento hispânico chamado de Códice Mendoza, a fim de retratar a realidade da cultura asteca para o poder imperial espanhol.

\section{O Sistema tributário asteca}

Estudos sobre os vários aspectos organizacionais, políticos e econômicos dos astecas, como os de Smith e Hicks (2016), Flores (2012) e Berdan (1976), relatam que o império possuía dois tipos de províncias ou cidades-estados: as províncias que eram tributadas e as províncias estratégicas. As províncias tributárias eram as responsáveis pelo financiamento das atividades do poder central, através do pagamento de tributos sobre o que produziam e comercializavam.

Por volta de 1500, o império exigia tributos de 38 províncias (Hodge, 1998). Segundo Pedroza (1998, p. 96), "o tributo no império asteca era um elemento integral e altamente estruturado dentro de um sistema econômico complexo". Os tributos arrecadados pelo governo imperial e pelas cidades-estados, consistiam principalmente em alimentos, metais, armas, tecidos, peles e matérias-primas para a fabricação de produtos artesanais e serviços em obras públicas.

Os tributos cobrados na sociedade asteca foram divididos por Smith (2015) em dois grupos:

- Tributos arrecadados pelo poder central:
(a) sistema fiscal da Tríplice Aliança;
(b)sistema de entrega de donativos;
(c)sistema fiscal de cidades-estados conquistadas.

- Tributos cobrados pelas cidades-estados:
(d)imposto territorial;
(e)aluguel de propriedades rurais;
(f) trabalho rotativo;
(g)trabalhos públicos; 
(h)tarefas militares;

(i)impostos sobre os mercados;

(j)impostos de fornecimento militar;

(k)trabalho nos centros educacionais que formavam os jovens a partir dos 15 anos, para servirem à comunidade e para a guerra.

O (a)sistema fiscal da Tríplice Aliança determinava quais tributos deveriam ser pagos pelas regiões que formavam o império asteca. Negociadores do governo central estabeleciam quais tributos seriam cobrados e o calendário de pagamentos das cidades-estados incorporadas ao império.

Os tributos recebidos pela Tríplice Aliança e registrados na Matrícula de Tributos poderiam ser divididos, conforme Smith (2015), em quatro categorias: (1) alimentos: como milho, amaranto, feijão e chia; (2) bens utilitários: como tigelas de cabaça e folhas de papel nativo; (3) têxteis: como tangas, túnicas e saias femininas, grandes mantas brancas, mantas brancas com bordas multicoloridas e mantas divididas diagonalmente; e, (4) trajes de guerreiros: como trajes vermelhos com escudo de diferentes tipos e outros trajes de guerreiros com escudos.

O (b)sistema de entrega de donativos à Tríplice Aliança foi um sistema tributário, segundo Smith (2015), que não gerava registro na Matrícula de Tributos. Esse sistema era implementado, normalmente, em regiões distantes do poder central do império, mas em áreas estratégicas e fundamentais para manter as fronteiras inimigas sem riscos de conflitos e invasões.

O terceiro tipo de tributo imperial era o (c)sistema fiscal das cidades-estados conquistadas. Como já existiam muitos impérios anteriores à Tríplice Aliança, essas regiões, mesmo depois de incorporadas ao império asteca, continuavam cobrando tributos de seus súditos e repassando parte para o governo imperial dominante. Os tributos devidos para a Tríplice Aliança eram registrados na Matrícula de Tributos. No momento da conquista, a taxa imposta pela Tríplice Aliança era de $40 \%$ do total arrecadado pela região conquistada (Smith, 2015).

Os registros da movimentação dos tributos nos códices eram realizados por funcionários do governo conhecidos como calpixques. Os calpixques deveriam residir nas localidades onde os tributos eram cobrados e seguir um calendário de tributação estabelecido pelo governo central. Eram comandados pelos petlacalcatl, que eram uma espécie de governadores indicados pelo poder imperial e ficavam nos centros mais importantes do território asteca (Cuervo, 2015). Os calpixques eram temidos pelo povo, pois possuíam autonomia para comandar castigos caso os devedores de tributos não saldassem suas dívidas. Porém, eles poderiam ser punidos até com a morte, extensiva a sua linhagem, caso registrassem nos códices informaçóes erradas ou falsas.

A casa dos livros, ou Amoxcalli, servia como biblioteca e arquivo dos códices, tendo como guardiões os sábios locais, chamados de tlamatinis e como escribas dos livros os tlacuilos (Tello, 2012; Ronco \& Martorelli, 2008).

\section{A Matrícula de tributos}

Rosado (2007a, p. 31) sugere que o códice denominado como Matrícula de Tributos foi provavelmente elaborado em uma data anterior a 1519 , considerando "o formato do documento e os estilos dos diferentes escribas".

Esse códice, formado por 16 peças e hoje preservado na Biblioteca do Museu Nacional de Antropologia e História, na Cidade do México, de acordo com Rojas (1995), Rosado (2007a) e Huerta e Berthier (2004), no seu formato atual é composto por 16 folhas com pinturas de ambos os lados, portanto, contém 32 páginas, as quais são cortadas e coladas em folhas mais finas, com $42-43$ centímetros de altura por 29 centímetros de largura. 
Rosado (2007b) defende que a Matrícula de Tributos deve ter sido escrita por, pelo menos, seis escribas em folhas individuais. Podem ter sido incluídas novas folhas ou modificadas as existentes ao longo dos anos devido à necessidade de se adaptar às mudanças na sociedade asteca, como novas conquistas de terras para o império, a mudança de ativos produzidos pelas comunidades e outros fatores susceptíveis de gerar alterações nos tributos devidos ao império central.

Na parte inferior de cada folha eram pintados, partindo do lado esquerdo e formando uma linha, os glifos toponímicos dos povos que formavam uma província tributária. Essa linha podia continuar pela borda direita, pela parte superior da folha da direita para esquerda e, ainda, descer pelo lado esquerdo, seguindo o sentido anti-horário, caso o número de povos fosse grande o suficiente para ocupar todas as bordas da folha. A parte central da folha foi ocupada com as figuras dos bens devidos pela cidade-estado ao poder central do império (Huerta \& Berthier, 2004).

É possível encontrar na Matrícula de Tributos algumas anotações em espanhol sobre as imagens, feitas após a invasão espanhola, que indicam o tipo e a quantidade de tributos devidos. A disposição dos bens devidos pela cidade-estado na folha era de baixo para cima, os têxteis nas primeiras linhas inferiores, seguidos dos trajes de guerreiros, com ou sem escudos, depois os produtos agrícolas e por fim algum tipo de tributo específico cobrado da província tributária (Huerta $\&$ Berthier, 2004). Esses comentários em espanhol foram utilizados na tradução para os invasores dos escritos na linguagem nabuatl ou para acrescentar informações que nem sempre coincidem com as pinturas originais (Núñez, 1968).

Além das imagens das cidades e dos bens devidos pelas cidades-estados na forma de tributos ao império asteca, a Matrícula de Tributos, posteriormente transcrita para o Códice Mendoza, adotava símbolos com o intuito de representar a quantidade dos bens devidos, conforme figura 2.

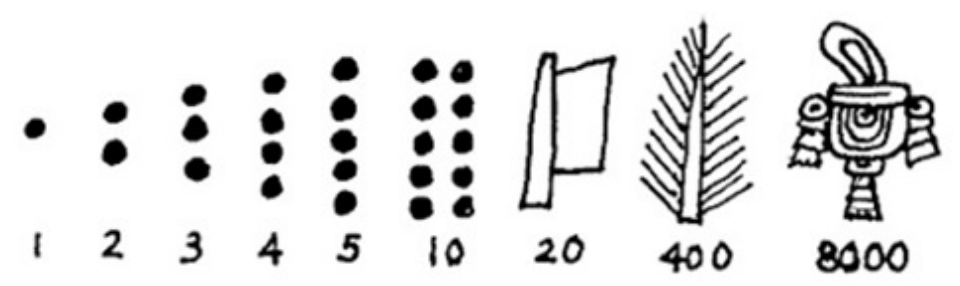

FIGURA 2

Sistema numérico asteca

Fonte: Marty (2006).

A partir da determinação dos fatores componentes da Matrícula de Tributos (glifos toponímicos representando os povoados, figuras retratando os bens devidos por eles e os símbolos numéricos) foi possível que os calpixques pintassem as páginas que depois foram reunidas para formar um único documento. A figura 3 apresenta a página 15 da Matrícula de Tributos. 


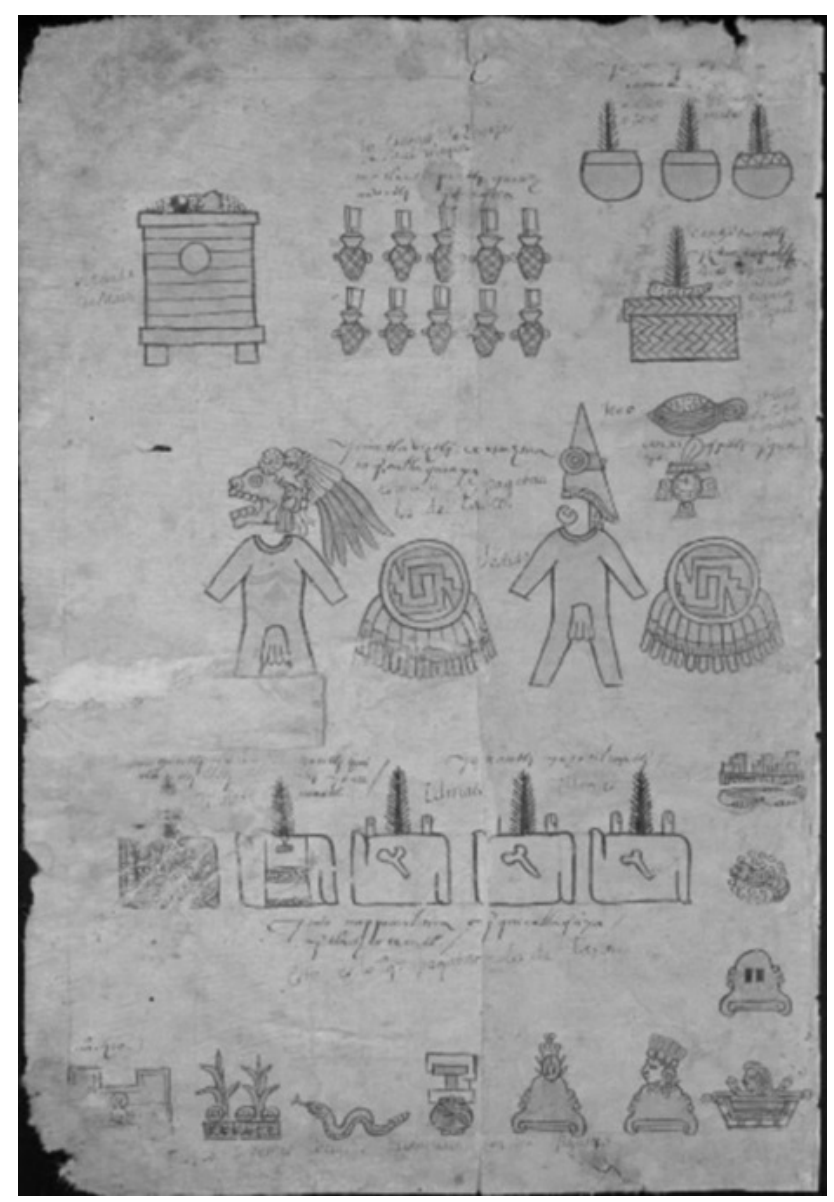

FIGURA 3

Página 15 da Matrícula de Tributos

Fonte: "Rolo de Tributos" de Biblioteca Digital Mundial (2019).

Nessa página da Matrícula de Tributos é possível identificar todos os elementos que compõem o códice. $\mathrm{Na}$ primeira linha inferior são apresentados os glifos toponímicos representantes dos povos que formam a província (cidade-estado) tributária de Tlachco (figura 4), identificados da esquerda para a direita os das cidades de Tlachco (principal cidade dessa província), Acamilyxtlahuacan, Chontalcoathan, Teticpac, Nochtepec, Teotliztacan e Tlamacazapan (última cidade da primeira linha de baixo) e no lado direito da folha de baixo para cima as cidades de Tepexahualco, Tzicapuçalco e Tetenanco (Berdan \& Anawalt, 1997).

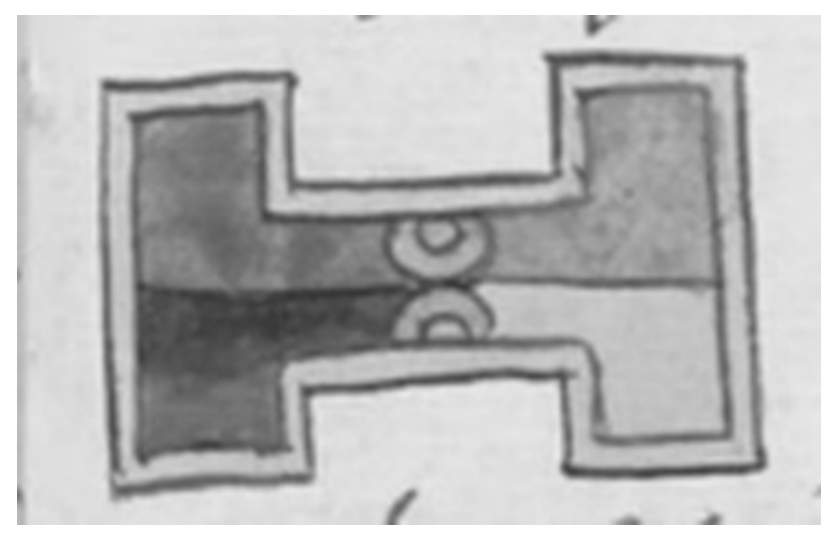

FIGURA 4

Glifo toponímico da província de Tlachco

Fonte: Bodleian Libraries (2019). 
Além das cidades que compõem a província de Tlachco, consegue-se identificar quais tributos eram devidos e as quantidades que deveriam ser entregues ao poder central do império asteca.

$\mathrm{Na}$ segunda linha da figura 3, da esquerda para a direita, constata-se que a província devia 400 mantas de algodão ricamente decoradas (embora a primeira imagem da esquerda dessa linha na Matrícula de Tributos esteja um pouco apagada dificultando a visualização, pode-se reconhecer a pena sobre a imagem, o que caracteriza a dívida de 400 peças), 400 túnicas e saias femininas (2a imagem da linha) e 1200 (400 peças x 3 figuras) mantas grandes henequen (feitas de fibras de sisal) brancas. Segundo Berdan e Anawalt (1997), essas peças deveriam ser entregues ao poder central a cada seis meses.

É possível também distinguir na terceira linha um traje de guerreiro tzitzimitl amarelo, um escudo, um traje de guerreiro cuextecatl amarelo e um escudo. A descrição desses trajes pode ser aprofundada no estudo de Kenney (2015). Um pouco acima dos trajes aparecem duas figuras, uma indica o numeral 8000 e a outra representa bolas de copal não refinadas, envoltas em folhas de palmeira. Copal é uma planta da região mexicana. O tributo na forma de trajes deveria ser pago uma vez por ano e as bolas de copal a cada oitenta dias (Berdan \& Anawalt, 1997).

Na próxima linha superior aparece a figura de uma caixa com alimentos, o que significa que a região devia uma caixa de milho e uma de feijão. Ao lado dessa caixa, estão desenhados 10 pequenos jarros com uma bandeira, representando a dívida tributária de 200 (10 x 20) jarros de mel de abelha. Junto aos jarros, está um cesto com uma pena indicando que a região teria a obrigação de disponibilizar 400 pequenos cestos de copal branco refinados para serem utilizados como recipiente para incensos e um pouco acima três imagens de cabaças com penas, isto é, uma dívida de 1200 ( 3 x 400) taças de cabaça amarelas envernizadas. Conforme Berdan e Anawalt (1997), as caixas de milho de feijão, os jarros de mel, os cestos de copal e as taças de cabaça deveriam ser entregues a cada oitenta dias.

Assim como a região de Tlachco tinha as suas dívidas tributárias registradas na Matrícula de Tributos, todas as demais províncias possuíam suas próprias dívidas. Analisando as páginas da Matrícula de Tributos, percebese que não existe um padrão tributário para todo império. Cada província tinha suas dívidas definidas a partir de negociações entre os líderes locais e os reis que formavam a Tríplice Aliança.

Com a chegada dos espanhóis comandados por Hernán Cortés, em 1519, a mando do Imperador da Espanha Carlos I, o império asteca caiu nas mãos dos conquistadores depois de dois anos de conflitos (Universidad Nacional Autónoma de México, 2019).

A invasão espanhola criou uma nova ordem social para a região ocupada, chamada de Nova Espanha, que trouxe uma sucessão de catástrofes, imposições através do uso da força bruta, agressão contra a cultura local e inclusive a destruição pelos invasores de quase toda a cultura documental asteca (Tello, 2012). Porém, a Matrícula de Tributos não só permaneceu intacta, senão que serviu de modelo para a elaboração de um novo códice denominado de Códice Mendoza.

\section{Códice Mendoza}

O Códice Mendoza foi produzido em 1541, duas décadas após a invasão espanhola ao império asteca, e teve a Matrícula de Tributos como um dos modelos para a sua criação (Rojas, 1995). De acordo com Martins (2017) e Rojas (1995), o Códice Mendoza está arquivado na Bodleian Library, em Oxford, Inglaterra.

\section{Estrutura do Códice Mendoza}

Esse códice foi elaborado com 71 folhas (142 páginas numeradas contando frente e verso), mede 32,7 centímetros de altura e 22,9 centímetros de largura, é feito de papel europeu e pintado por um único tlacuilo (escriba). Produziu-se por demanda do vice-rei da Nova Espanha Antonio de Mendoza como um documento 
a ser enviado para o imperador Carlos V, no entanto, foi roubado por piratas franceses na viagem para a Espanha e passou por diversos colecionadores até chegar no museu de Oxford (Martins, 2017; Ronco \& Martorelli, 2008).

O Códice Mendoza escreveu-se utilizando textos alfabéticos em espanhol e registros na linguagem nahuatl, com comentários em espanhol ou em nabuatl (Martins, 2017).

O documento foi construído em três partes: as páginas 1 a 18 (frente) foram dedicadas aos registros históricos do povo asteca, as páginas 18 (verso) a 55 (frente) serviram para os registros tributários devidos pelas províncias à Tríplice Aliança e as páginas 56 (verso) a 71 (verso) foram destinadas aos registros etnográficos dos astecas. As páginas 55 (verso) e 56 (frente) estão em branco. No verso da página 18 aparece a descrição detalhada em espanhol do significado de todos registros da página 19 (frente) escritos na linguagem nabuatl. Todas páginas destinadas ao detalhamento dos tributos seguem essa lógica: primeiro vem uma página com as explicações em espanhol e depois a cópia da página com o detalhamento da Matrícula de Tributos (Rosado, 2007b; Berdan \& Anawalt, 1997; Bodleian Libraries, 2019).

\section{Segunda parte do Códice Mendoza: registros tributários}

A segunda parte do Códice Mendoza, composta pelas páginas 18 (verso) a 55 (frente), corresponde à transposição quase integral da Matrícula de Tributos (Rojas, 1995).

Para Rojas e Batalla (2008), a cópia no Códice Mendoza de informações da Matrícula de Tributos está evidenciada pelas quantidades totais de tributos devidos pelas províncias. A tabela 1 apresenta exemplos de tributos que deveriam ser pagos com mantas de algodão e de ixtli (espécie de Agave originária do México) e com túnicas e saias femininas, registrados inicialmente na Matrícula de Tributos e, posteriormente, no Códice Mendoza. As diferenças de valores podem ser justificadas, em conformidade com Rosado (2007a), tendo em conta que o Códice Mendoza não era um documento oficial como a Matrícula de Tributos, mas um livro de registros para mostrar ao imperador espanhol como funcionava o modo de vida dos astecas, razão pela qual foi dividido em três partes.

TABELA 1

Exemplos de tributos a serem pagos pelas províncias ao império asteca

\begin{tabular}{|c|c|c|}
\hline \multicolumn{1}{|c|}{ Tipos de Tributos } & $\begin{array}{c}\text { Quantidade no Códice de } \\
\text { Mendoza em unidades }\end{array}$ & $\begin{array}{c}\text { Quantidade na Matricula } \\
\text { de Tributos em unidades }\end{array}$ \\
\hline Mantas de algodão brancas & 568.000 & 560.000 \\
\hline $\begin{array}{l}\text { Mantas de algodão } \\
\text { trabalhadas }\end{array}$ & 608.800 & 478.200 \\
\hline Mantas de $i x t l i$ & 96.000 & 48.000 \\
\hline Túnicas e saias femininas & 180.000 & 164.000 \\
\hline Total & $\mathbf{1 . 4 5 2 . 8 0 0}$ & $\mathbf{1 . 2 5 9 . 2 0 0}$ \\
\hline
\end{tabular}

Fonte: adaptado de Rojas e Batalla (2008).

Analisando o Códice Mendoza através da hipermídia disponível na página da Bodleian Libraries (2019), é possível explorar a versão digital das três partes do documento.

A página 35 (verso) apresenta em espanhol todos os detalhes da página 36 (frente) do Códice Mendoza. A página 36 (frente), por sua vez, replica a página 15 da Matrícula de Tributos (figura 3), contudo, observase uma inversão na disposição das imagens, pois o glifo toponímico da província de Tlachco aparece como a primeira figura na parte superior do lado esquerdo da folha, conforme a figura 5. Na Matrícula de Tributos, a apresentação dos glifos das cidades que formam a província de Tlachco parte do lado esquerdo inferior da folha. 


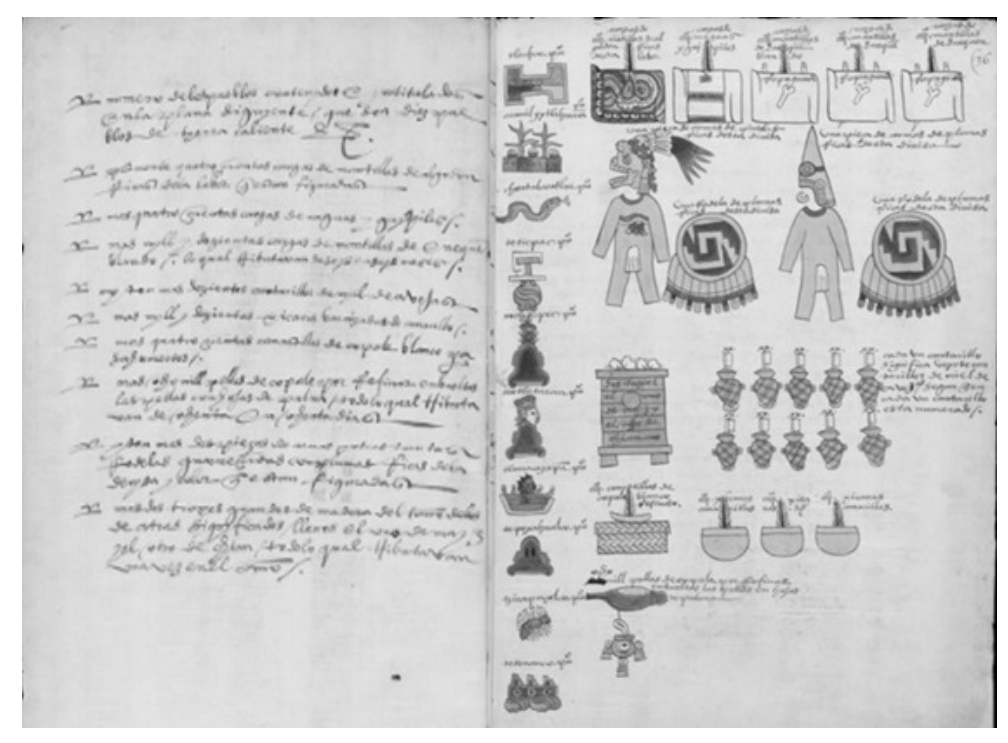

FIGURA 5

Página 35 (verso) e 36 (frente) do Códice de Mendoza Fonte: Bodleian Libraries (2019).

Do mesmo modo, o registro das dívidas tributárias da província de Tlachco, que aparece na página 36 (frente), não segue a mesma disposição da página 3 da Matrícula de Tributos (figura 3), embora as figuras sejam as mesmas.

No Códice Mendoza são detalhadas em espanhol as dívidas de 400 mantas de algodão ricamente decoradas (página 35 verso), 400 túnicas e saias femininas ( $2^{\mathrm{a}}$ imagem da $1^{\mathrm{a}}$ linha da página 36 frente) e 1200 (400 peças x 3 figuras) mantas grandes henequen (feitas de fibras de sisal) brancas, que aparecem na primeira linha superior da página 36 (verso), ao contrário da apresentação na Matrícula de Tributos onde figuram na primeira linha inferior (figura 3). Uma sequência inversa idêntica é utilizada para exibição do traje de guerreiro tzitzimitl amarelo e um escudo e do traje de guerreiro cuextecatl amarelo e um escudo, que foram registrados no códice na segunda linha. Após os trajes aparecem as caixas de milho e de feijão, os $200(10 \times 20)$ jarros de mel de abelha, abaixo 400 pequenos cestos de copal branco refinados, 1200 (3 x 400) taças de cabaça amarelas envernizadas e na última linha 8000 bolas de copal não refinadas, envoltas em folhas de palmeira.

A mesma lógica de demonstração dos tributos devidos pelas 38 províncias tributárias foi utilizada em todas as páginas da segunda parte do Códice Mendoza: primeiro a explicação em espanhol dos tributos devidos e depois a apresentação na linguagem dos astecas.

\section{Exame da Matrícula de Tributos e da Segunda Parte do Códice Mendoza sob a Dimensão da Nova História da Contabilidade}

A partir da descrição detalhada da Matrícula de Tributos e da segunda parte do Códice Mendoza, conseguese analisar esses objetos materiais sob a ótica da NHC, como parte da Nova História Cultural.

A prática das pesquisas históricas tem sido direcionada para novos caminhos nos quais as imagens, os textos e as ações passaram a ter um papel de destaque como elemento interpretativo do passado, especialmente a partir das últimas décadas do século XX (Hunt, 1992). Burke (1997) e Hunt (1992), entre outros historiadores, passaram a denominar essa fase como Nova História Cultural, sendo que a partir desses novos diálogos multidivisionais, outras disciplinas assumiram esse conceito de Nova História, como foi o caso da NHC, que buscou ampliar o seu campo histórico investigativo. 
Esteve (1997) defende que essa nova perspectiva de estudo da história da Contabilidade, conduz a um campo de análise onde o foco não pode ser unicamente voltado para a análise técnica da Contabilidade, mas que entende esse elemento como parte de um contexto social e organizado dentro de uma sociedade. Miller (1994) corrobora esse pensamento ao defender que para o entendimento das formas particulares da Contabilidade é preciso que o pesquisador vá além dos limites da organização e passe a examinar a prática social e institucional em que a Contabilidade está inserida. Assim, percebe-se que esse novo cenário de estudo da história da Contabilidade passa a vislumbrar aspectos sociais e comportamentais como influenciadores das práticas contábeis e tributárias de antigas sociedades.

Definir objetivamente esse novo contexto da História Cultural, na visão de Burke (2005), seria tão difícil como tentar prender uma nuvem numa rede de caçar borboletas, dado que constitui um campo historiográfico multidisciplinar onde se articulam aspectos econômicos, mentais e sociais de situações históricas. As pessoas, dentro dos conceitos da Nova História Cultural, são formadas a partir do meio em que vivem.

Ao trazer esse conceito para a conjuntura social e organizacional da sociedade asteca, considerando em especial que, conforme Smith (2015), o principal objetivo da expansão territorial do império era subjugar os povos conquistados e forçá-los a pagar tributos para o poder central, tem-se que o povo subjugado passou a viver, pelo menos em parte, para sustentar a nobreza asteca. Com o passar do tempo, essa nova realidade se tornou um modo de vida das populações anexadas ao império asteca, ou seja, o tributo ao novo imperador e outros tantos fatores da vida cotidiana passaram a fazer parte do cotidiano dessas pessoas.

Uma análise da Matrícula de Tributos e a segunda parte do Códice Mendoza sob o ponto de vista da História Tradicional da Contabilidade estaria focada na dimensão técnica do registro contábil dos tributos, e observaria os documentos como um simples sistema de mensuração e comunicação de dívidas tributárias ao poder central asteca. Como afirma Gomes (2008), a visão técnica da Contabilidade sempre foi a predominante, privilegiando as características de neutralidade, objetividade e utilidade para a tomada de decisões da elite dominante.

Pelo contrário, dentro do contexto da Nova História, segundo Barros (2011), o exame passa a ser dos objetos culturais produzidos, dos sujeitos produtores e receptores da cultura de um povo, dos processos que envolvem a produção e difusão cultural, dos sistemas constituídos que dão suporte aos processos de produção e das normas instituídas para que a cultura seja produzida. Ao examinar esses fatores, os novos historiadores culturais buscam identificar quais são as principais práticas e representações de determinados objetos historiográficos. Além disso, defende que "o confronto entre duas sociedades, relacionadas a duas culturas distintas pode oferecer uma possibilidade exemplar de iluminar uma cultura através da outra" (Barros, 2011, p. 40).

Dentro da nova perspectiva de análise dessa realidade a partir da NHC, é possível perceber que a chegada dos colonizadores hispânicos criou uma nova ordem social para a região ocupada, marcada por uma sucessão de guerras e imposições que buscavam, notadamente através do uso da força bruta, a implementação de uma nova cultura dominante e a eliminação de toda cultura local, inclusive com o banimento de quase todos os documentos astecas. Para Iglésias (1992, p. 28) "o conquistador não vinha para catequizar, converter ao cristianismo, mas para obter riquezas". Porém, mesmo com a eliminação quase que na integralidade da memória cultural e documental asteca, a Matrícula de Tributos permaneceu intacta e serviu de modelo para a criação do Códice Mendoza. Iglésias (1992, p. 28) afirma que "se os iberos muito determinaram, com imposições que não recuavam ante a violência mais crua, também aprenderam bastante com os nativos. Se deram práticas, produtos, técnicas, usos e crenças, também aprenderam práticas, produtos, técnicas, usos e até crenças". Como já destacado anteriormente, apenas nove códices astecas pré-hispânicos se salvaram da destruição depois da invasão espanhola.

O confronto entre essas duas sociedades exemplifica o que os novos historiadores culturais chamam de iluminar uma cultura através da outra. Para Barros (2011, p. 40), "o confronto entre duas sociedades, relacionadas a duas culturas distintas pode oferecer uma possibilidade exemplar de iluminar uma cultura 
através da outra”. Mesmo que praticamente toda a cultura asteca tenha sido destruída pelos espanhóis, eles perceberam que a Matrícula de Tributos era uma ferramenta importante de contabilização dos tributos que poderia ser utilizada como um modelo para comunicar ao Imperador da Espanha toda complexidade tributária vivida por aquela sociedade, tanto que foi transcrita quase que na integralidade para o Códice Mendoza.

Para Carmona, Ezzamel e Gutiérrez (2004), a NHC deve desvendar o cenário sociopolítico que originou as práticas contábeis do passado. $\mathrm{O}$ momento sociopolítico vivido pelos astecas após a invasão espanhola abrange uma aproximação inicial necessária entre os povos, especialmente no processo de comunicação. Para Morais (2006), astecas designados por Montezuma e espanhóis conseguem pôr ordem nos diálogos entre eles desde o início da ocupação. A comitiva invasora contava com dois tradutores: Jerónimo de Aguilar e Malinnczin. "Esta última entendia as palavras dos índios ditas em nabuatl, comunicava a Aguilar em maia e finalmente Aguilar traduzia em castelhano para que os conquistadores pudessem entender" (Portilla, 2003, p. 37). Historicamente, o entendimento da linguagem asteca, ainda que através de tradutores, permitiu que os espanhóis se apoderassem não somente dos bens, mas de outros elementos importante da cultura asteca como a Matrícula de Tributos.

Para Martín (2006), a visão de baixo para cima da NHC faz com que o pesquisador busque diferentes formas contábeis utilizadas pelas sociedades antigas, como fichas de barro, quipus, entre outros, assim como os códices astecas.

O Códice Mendoza é um documento que traduz, dentro da perspectiva da NHC, uma fusão cultural dos dois povos e um espelhamento da forma de representar contabilmente os tributos dessa sociedade, pois incorpora textos alfabéticos em espanhol para explicar os registros da linguagem nabuatl (figura 6), além de utilizar os mesmos glifos toponímicos para representar os povos que formavam as províncias tributárias, bem como as figuras retratando os tributos devidos e os símbolos numéricos.

Outro conceito recorrente nas abordagens recentes da Nova História, conforme já destacado por Barros (2011), diz respeito às práticas e as representações dos objetos culturais dos povos historicamente estudados. Para Barros (2011, p. 46), "os objetos culturais seriam produzidos entre práticas e representações, como os sujeitos produtores e receptores de cultura", evidenciando às formas de fazer e de ver esses objetos.

As práticas culturais, conforme Burke (2005) e Chartier (1995), devem ser examinadas a partir do olhar dos vários agentes que as produzem, das técnicas utilizadas para as suas realizações e dos usos e costumes utilizados pela sociedade que adota determinadas práticas. As representações caracterizam-se "como um repertório de modelos de comportamento, como um conjunto de representações que são igualmente normas imitáveis (e possivelmente imitadas)" Chartier (1995, p. 187).

Portanto, do ponto de vista da Nova História da Contabilidade, na análise das práticas e as representações dos objetos culturais do povo asteca percebe-se claramente que a produção do Códice Mendoza incorporou na sua construção elementos pertencentes à cultura asteca, como o modo de redigir utilizando a escrita nahuatl, através de glifos toponímicos para representar as províncias tributárias, das figuras retratando os tributos devidos e dos símbolos numéricos que eram os mesmos utilizados na Matrícula de Tributos, espelhando uma cultura através da outra. $\mathrm{O}$ modo de contabilizar os tributos devidos pelas províncias exibe o modo de escrever, de pensar e de externalizar o sistema tributário asteca. Quando os tlacuilos (escribas) produziram a Matrícula de Tributos, adotaram representações próprias da sua cultura, como o gênero representativo utilizado pelos astecas em outros códices, seguindo a prática consolidada na sua cultura.

O conteúdo da Matrícula de Tributos tinha ressonância em todo território asteca, o que gerava práticas sociais, já que seu conteúdo impunha regras tributárias que deveriam ser cumpridas peremptoriamente em toda a sociedade, caracterizava uma representação coletiva, moldava um padrão de arrecadação tributária incutido pelo poder dominante e, desta forma, traduzia o modo de pensar e de agir do poder central. A Matrícula de Tributos era, por conseguinte, um elemento associado ao imaginário do poder absoluto do imperador, ou seja, uma representação do imaginário político da centralização do poder de origem 
hereditária e divina. Essa característica não foi repassada para o Códice Mendoza, visto que era um objeto de representação das caraterísticas da cultura asteca e não um instrumento oficial de contabilização tributária como a Matrícula de Tributos.

Outro conceito fundamental para a Nova História é a ideologia produzida a partir da interação entre as representações e comportamentos que regem uma sociedade e associada ao poder e ao controle social exercidos sobre uma comunidade (Barros, 2011).

A sociedade asteca era estratificada por uma classe social nobre, de natureza hereditária e dominante, que constituía aproximadamente $5 \%$ da população e os demais $95 \%$ que formavam a classe dominada. Essa parcela da população era a principal responsável pelo pagamento dos tributos, com exceção dos religiosos, menores, órfãos, inválidos e mendigos. Sob a perspectiva da Nova História da Contabilidade que salienta a interação entre as representações e comportamentos que regem uma sociedade, observa-se que a ideologia imposta para essa classe dominada através do total controle social, impôs uma clara hierarquia de separação de classes, atribuindo regras tributárias incontestáveis, tanto que as representações da Matrícula de Tributos não poderiam ser impugnadas pois, como já destacado, o não pagamento pelos devedores poderia gerar punições como a escravidão, o confisco dos bens e outras severas penalidades, inclusive intervenções militares nas regiões que se rebelassem e não cumprissem suas obrigações tributárias.

Dentro do contexto da Nova História insere-se a História da Cultura Material, que, segundo Prown (1982, p. 1), "é o estudo através de artefatos das crenças-valores, ideias, atitudes e suposições de uma determinada comunidade ou sociedade em um determinado momento".

A análise da Matrícula de Tributos, do ponto de vista da abordagem da Nova História da Contabilidade, focada na Cultura Material e direcionada para o estudo do domínio histórico dos ambientes sociais dos astecas e de seus objetos de contabilização de tributos, possui uma característica polissêmica, pois pode ser apontada tanto para o exame de seus aspectos materiais como de suas características imateriais. As características tangíveis da Matrícula de Tributos já foram amplamente estudadas partindo dos seus aspectos antropológicos, codicológicos, mitológicos, sociológicos, do exame dos pictogramas, de suas formas gráficas e da análise de vários elementos relacionados com a preservação do patrimônio cultural, dentre outras possíveis óticas. Porém, os objetos materiais também podem ser estudados a partir de seus atributos intangíveis como as crenças, valores, ideias ou postulados que estejam associados as suas características físicas.

Assim, dentro desse enquadramento da Nova História da Contabilidade com foco na Cultura Material, a Matrícula de Tributos traz intrinsecamente, junto com suas características físicas e atributos intangíveis, uma representatividade do poder divino do imperador. As determinações tributárias contabilizadas na Matrícula de Tributos eram incontestáveis: os calpixques, funcionários do governo que cobravam os tributos a partir da Matrícula de Tributos, eram temidos pelo povo porque possuíam autonomia para comandar castigos caso os devedores de tributos não saldassem suas dívidas, mas do outro lado poderiam ser punidos até a morte, extensiva a sua linhagem, caso os registros e a gestão tributária não estivessem corretos. Essa característica intangível da Matrícula de Tributos insere-se na chamada teoria do reflexo, onde um objeto de uma cultura material é reflexo de uma cultura concebida como patrimônio abstrato, alheio a toda materialidade (Rede, 1996). A Matrícula de Tributos exala, deste modo, as características de sua civilização e traz na sua essência o espírito divino e o poder opressor do imperador asteca. O mesmo não se aplica ao Códice Mendoza, devido a seu propósito de simples representação de uma cultura.

\section{Considerações finais}

Esse estudo objetivou examinar a Matrícula de Tributos, e sua posterior transcrição para o Códice Mendoza, como elemento de contabilização dos tributos no império asteca dentro da dimensão da Nova História da 
Contabilidade, com abordagem de pesquisa na História da Cultura Material e se direcionou para o domínio histórico dos ambientes sociais dos astecas e de seus objetos de controle tributário.

Desde a criação da chamada Tríplice Aliança no século XIII, com a união das regiões de Tenochtitlán, Texcoco e Tlacopan, que formaram o centro do império asteca, a gestão tributária foi um fenômeno instituído como parte da cultura dessa sociedade.

O exame da Matrícula de Tributos e do Códice Mendoza através da Nova História da Contabilidade permitiu identificar os inter-relacionamentos de duas culturas. A Matrícula foi um dos principais elementos de contabilização para os astecas e, mesmo que o colonizador espanhol tivesse o objetivo de subjugar essa cultura, serviu de espelho para a criação de um códice que visou apresentar ao imperador além-mar as principais características da nova região dominada pela Espanha. Essas evidências de iluminação dos registros tributários astecas na cultura dos invasores espanhóis corroboram as afirmações de Barros (2011) e Carmona, Ezzamel e Gutiérrez (2004), na medida em que a NHC deve desvendar o cenário sociopolítico que originou as práticas contábeis do passado. Assim então, esse estudo pôde contribuir com uma análise sob a perspectiva da nova história de como a contabilização dos tributos, através da Matrícula de Tributos, foi parte do desenvolvimento cultural dos astecas e do seu espelhamento na cultura dos colonizadores espanhóis.

Culturalmente, a Matrícula de Tributos representou para os astecas um dos principais elementos de tradução do poder imperial sobre o povo. A caraterística opressora da cobrança, e a certeza de que nada sairia desconforme das imagens pintadas no livro, fazia com que os envolvidos, tanto os que representavam o opressor como os oprimidos, temessem pelo não acertamento da gestão tributária, considerando que a penalização pelas incorreções poderia ser a morte não apenas dos implicados diretos, mas de seus familiares.

É inegável que a Matrícula de Tributos representou um agente de grande importância para a sobrevivência do império, tanto pelo aspecto arrecadatório como de hierarquização da sociedade asteca, dado que ele simbolizava a determinação advinda da figura divina do imperador e estabelecia quanto cada distrito deveria contribuir para a manutenção dessa estrutura de forma indeclinável. Assim, sob o ponto de vista da NHC, fica latente como a contabilização dos tributos representou mais que uma simples dívida e traduziu uma forma de demostrar o poder imperial sobre as comunidades subjugadas. Os registros tributários constituíam um objeto cultural, em conformidade com as afirmações de Barros (2011), que representavam os papéis de todos atores envolvidos naquele contexto social: o poder central como sujeito produtor e difusor da cultura opressora e o povo como elemento cultural receptor.

Desta maneira, é possível ter na Matrícula de Tributos e no Códice Mendoza elementos passíveis de estudo dentro do contexto da Nova História da Contabilidade, analisando-se o conjunto de circunstâncias de tempo e espaço, de emissor e de receptor, buscando uma forma particular de compreensão da Contabilidade, investigando os limites organizacionais daquela sociedade em particular, de suas práticas sociais e institucionais, não focando a análise em uma dimensão técnica do registro contábil dos tributos e não observando os documentos como um simples sistema de contabilização das dívidas tributárias da sociedade. Essa análise, portanto, vai ao encontro do que defende Esteve (1997) quando afirma que a nova perspectiva de estudo da História da Contabilidade deve focar na análise do contexto social e organizado de uma sociedade e não apenas no estudo da Contabilidade como uma técnica.

Embora estudar História da Contabilidade em países da América do Sul seja uma tarefa árdua, pois são poucos os pesquisadores interessados no tema, poucas as instituições de ensino superior que possuem a disciplina de História da Contabilidade em seus cursos de graduação e pós-graduação e, principalmente, poucos os periódicos que publicam estudos dessa área, um trabalho focado na Nova História da Contabilidade torna a tarefa ainda mais custosa, levando em consideração que é uma nova perspectiva dentro de um campo ainda pouco explorado.

Neste panorama, esse estudo buscou contribuir com esse novo horizonte que se abre para o estudo da História da Contabilidade, ao evidenciar a importância de como a contabilização dos tributos astecas, através da Matrícula de Tributos, possibilitou a sobrevivência do status quo do poder central da Tríplice Aliança e 
como esse instrumento contábil serviu de espelho para a criação de um documento de divulgação sobre a Nova Espanha.

Além disso percebeu-se que, não muito distante do que acontece hoje em dia, a complexidade tributária já fazia parte das sociedades antigas. $\mathrm{O}$ mundo capitalista atual, assim como nas terras astecas, tem no tributo uma das principais fontes de financiamento da estrutura administrativa central dos governos. A carga tributária da realidade vigente em muitos países latinos, segundo a Organização para a Cooperação e Desenvolvimento Econômico - OCDE (2019), representa parcelas significativas da receita arrecadada. Em 2017 a carga tributária em Cuba chegou a 40,6\% do Produto Interno Bruto (PIB); no Brasil, a 32,3\%; em Barbados, a 31,8\%; no Uruguai, a 30,9\%; e na Argentina, a 30,3\%. Nos demais países latinos a carga foi menor que $30 \%$ do PIB. Nota-se, com esse atual panorama tributário que, mesmo passados 500 anos da chegada dos conquistadores europeus nas Américas, a cultura arrecadatória adotada pelos Astecas, como o principal elemento de financiamento da máquina pública, continua sendo uma prática corrente em muitos países.

No transcorrer deste estudo identificaram-se algumas questões correlativas que permitiriam o desenvolvimento de novos estudos relacionados com o uso da Nova História da Contabilidade com abordagem na Cultura Material, especialmente direcionadas para a análise de objetos de outras sociedades americanas que utilizavam mecanismos próprios para o controle tributário, como os incas que utilizavam os Quipus e os maias que utilizavam códices próprios.

\section{Referências}

Anthônio, J. (2017). O Barroco Latino e o olhar contrafeito. Cadernos de Estudos Culturais, 4(08). Disponível em: h ttps://desafioonline.ufms.br/index.php/cadec/article/view/3530

Barros, J. D. A. (2011). A Nova História Cultural-considerações sobre o seu universo conceitual e seus diálogos com outros campos históricos. Cadernos de História, 12(16), 38-63. https://doi.org/10.5752/P.2237-8871.2011v1 $2 \mathrm{n} 16 \mathrm{p} 38$

Bedoya-Salazar, C., Dreisigacker, S., Hearne, S., Franco, J., et al. (2017). Genetic diversity and population structure of native maize populations in Latin America and the Caribbean. Plos one, 12(4), 1-21, San Francisco, USA. Disponível em: https://journals.plos.org/plosone/article?id=10.1371/journal.pone.0173488

Berdan, F. F. (1976). La organización del tributo en el imperio azteca. Estudios de cultura nábuatl, 12, 185-195. Disponível em: https://dialnet.unirioja.es/servlet/articulo?codigo $=3833579$

Berdan, F., \& Anawalt, P. R. (1997). The Essential Codex Mendoza. Univ of California Press. https://doi.org/10.101 $7 /$ S0956536100001528

Biblioteca Digital Mundial. (2019, junho). Rolo de tributos. Disponível em: https://www.wdl.org/pt/item/3248/vie $\mathrm{w} / 1 / 20 /$

Bodleian Libraries. (2019, maio). Codex Mendoza. Disponível em: https://digital.bodleian.ox.ac.uk/inquire/ Discover/Search/\#/?p=c+0,t+,rsrs+0,rsps+10,fa+,so+ox\%3Asort\%5Easc,scids+,pid+2fea788e-2aa2-4f08b6d9-648c00486220,vi+17620bf5-967a-4b46-a33b-da1e4bb51fa8

Burke, P. (1992). A nova história, seu passado e seu futuro. A escrita da história: novas perspectivas. São Paulo: UNESP. Disponível em: http://etnohistoria.fflch.usp.br/sites/etnohistoria.fflch.usp.br/files/Burke_Nova_Historia.pdf

Burke, P. (1997). A escola dos Annales (1929-1989). São Paulo: UNESP.

Burke, P. (2005). O que é história cultural? Rio de Janeiro: Zahar.

Campos, F, \& Claro, R. (2013). Oficina de História, 1.ed. São Paulo: Leya.

Carmona, S. Ezzamel, M. \& Gutiérrez, F. (2004). Traditional and New Accounting History Perspectives. DE COMPUTIS Revista Española de Historia de la Contabilidad, 1(1), 24-53. http://dx.doi.org/10.26784/issn.18 86-1881.v1i1.239

Chartier, R. (1995). Cultura popular: revisitando um conceito historiográfico. Revista Estudos Históricos, 8(16), 179-192. Disponível em: http://bibliotecadigital.fgv.br/ojs/index.php/reh/article/view/2005 
Chartier, R. (2010). Escutar os mortos com os olhos. Estudos avançados, 24(69), 6-30. Disponível em: https://www.s cielo.br/scielo.php?pid=S0103-40142010000200002\&script=sci_arttext

Cuervo, A. C. (2015). Organización política y expansión militar en el Imperio Azteca. Grado en Historia, Facultad de Filosofíay Letras, Universidad de Valladolid. Disponível em: https://uvadoc.uva.es/handle/10324/16470

Esteve, E. H. (1997). História da contabilidade: passado rumo ao futuro. Revista de Contabilidade e Comércio, Figueira da Foz, Portugal, 55(216). Disponível em: http://www.apotec.pt/fo\%ADtos/editor2/HISTORIADACONT ABILIDADE.pdf

Fagundes, N. J. (2007). Origem do Homo sapiens e sua chegada às Américas: uma contribuição da antropologia molecular. Tese de Doutorado. Universidade Federal do Rio Grande do Sul. Instituto de Biociências. Programa de PósGraduação em Genética e Biologia Molecular. Disponível em: https://www.lume.ufrgs.br/handle/10183/109 60

Flores, C. T. (2012). Historia activa de Mexico. México DF: Editorial Progreso.

Gomes, D. (2008). The interplay of conceptions of accounting and schools of thought in accounting history. Accounting History, [S.L], 13(4), 479-509. https://doi.org/10.1177/1032373208095480

Guarinello, N. L. (2003). Uma morfologia da História: as formas da História Antiga. Politeia, 3(1), 41-62. Disponível em: https://moodle.ufsc.br/pluginfile.php/2454203/mod_resource/content/1/Guarinello\%202003\%20-\%20 Uma\%20morfologia\%20da\%20História.pdf

Hodge, M. G. (1998). Archaeological Views of Aztec Culture. Journal of Archaeological Research, 6(3), 197-238. Disponível em: https://link.springer.com/article/10.1023/A:1022876304931

Huerta, A., \& Berthier, E. (2004). Matrícula de tributos: un análisis. Antropología. Boletín Oficial del Instituto Nacional de Antropología e Historia, 73, 70-83. Disponível em: https://www.revistas.inah.gob.mx/index.php/antropolo gia/article/view/3002

Hunt, L. (1992). A nova história cultural. Tradução de Jefferson Luís Camargo. Revista de História, 133, 147-151. ht tps://doi.org/10.11606/issn.2316-9141.v0i133p147-151

Iglésias, F. (1992). Encontro de duas culturas: América e Europa. Estudos avançados, 6(14), 23-37. Disponível em: htt ps://www.scielo.br/scielo.php?pid=S010340141992000100003\&script=sci_arttext

Kenney, K. (2015). Ancient Aztecs (Ancient Civilizations). Minesot: Essential Library.

Maia, A. M. R. Costa, E., Padilha, M. I., \& Borenstein, M. S. (2011). Pesquisa Histórica: possibilidades teóricas, filosóficas e metodológicas para análise de fontes documentais. Revista Eletrônica Here, 2(1), 137-149. Disponível em: https://www.ets.ufpb.br/pdf/2013/2\%20Metodos\%20quantitat\%20e\%20qualitat\%20-\%20IFES/Livros \%20de\%20Metodologia/PESQUISA\%20HISTÓRICA\%20-\%20POSSIBILIDADES\%20TEÓRICAS, \%20FILOSÓFICAS\%20E\%20METODOLÓGICAS\%20PARA\%20ANÁLISE\%20DE\%20FONTES \%20DOCUMENTAIS.pdf

Martín, F. Q. (2006). Historia de la Contabilidad: Una revisión de las Perspectivas Tradicionales y Críticas de Historiografía Contable. Revista Facultad de Ciencias Económicas - Investigación y Reflexión, Colômbia, 14(1), 187-202. Disponível em: https://www.redalyc.org/pdf/909/90900110.pdf

Martins, E. H. G. (2017, agosto). Conquistas mexicas, conquistas castelhanas: a construção de uma crônica castelhana alternada com textos pictoglíficos indígenas na seção histórica do códice Mendoza. Anais - I Congresso de América Colonial - Historiografia, Acervos e Documentos Laboratório de Estudos Americanos - LEA. Campinas. Disponível em: http://paineira.usp.br/cema/images/ProducaoCEMA/EduardoHenriqueGorobetsMartins/C onquistasmexicasconquistascastelhanasaconstrucaodeumacronicacastelhana.pdf

Marty, L. (2006). Ancient Aztecs. Lorenz Educational Press, Dayton, OH. Disponível em: https://etd.ohiolink.edu/p g_10?0::NO:10:P10_ACCESSION_NUM:ucin1243014144

Melo, J. J. P. (2013). O império asteca e as escolas para a formação de guerreiros e sacerdotes. Série-Estudos-Periódico do Programa de Pós-Graduação em Educação da UCDB, 23. Disponível em: https://serie-estudos.ucdb.br/serie -estudos/article/view/268

Miller, P. (1994). Accounting as a Social and Institutional Practice: An Introduction, in A. Hopwood \& P. Miller (eds.), Accounting as Social and Institutional Practice (pp. 1-39), Cambridge: University Press. 
Morais, I. M. B. (2006). A história vista de baixo: a visão Asteca da conquista Espanhola. Ameríndia-História, cultura e outros combates, 2(1), 12. Disponível em: http://repositorio.ufc.br/handle/riufc/13915

Núñez, J. C. (1968). En Códices Mexicanos. Notas y comentários basados em Francisco A. Lorenzana y Códice Mendocino. Edición fac-similar. México DF: FCE.

Organização para a Cooperação e Desenvolvimento Econômico - OCDE (2019). Revenue Statistics in Latin America and the Caribbean 2019. Recuperado de: https://www.oecd.org/tax/tax-policy/revenue-statistics-in-latin-ame rica-and-the-caribbean-24104736.htm

Padilha, M. I. C., \& Borenstein, M. S. (2005). O método de pesquisa histórica na enfermagem. Texto \& Contexto Enfermagem, 14(4). Disponível em: https://www.redalyc.org/pdf/714/71414415.pdf

Pedroza, J. J. C. (1998). Historia activa de México. México DF: Editorial Progreso.

Petroni, M. C. A. (2004). Pensando as sociedades pré-hispânicas. Um estudo sobre a sociedade mexica e a conquista espanhola. Revista do Museu de Arqueologia e Etnologia, 14, 259-276. https://doi.org/10.11606/issn.2448-175 0.revmae.2004.89671

Portilla, M. L. (2003). Visión de los vencidos. Universidad Nacional Autónoma de México, México.

Prown, J. D. (1982). Mind in matter: An introduction to material culture theory and method. Winterthur portfolio, 17(1), 1-19. Disponível em: https://www.journals.uchicago.edu/doi/abs/10.1086/496065?journalCode=wp

Rede, M. (1996). História a partir das coisas: tendências recentes nos estudos de cultura material. Anais do Museu Paulista: História e Cultura Material, 4(1), 265-282. https://doi.org/10.1590/S0101-47141996000100018

Rojas, J. L. (1995). Los libros pictográricos de tributos: Códice Mendoza y Matrícula de Tributos. Universidad Complutense de Madrid, Madrid. Disponível em: https://dialnet.unirioja.es/servlet/articulo?codigo=121002

Rojas, J. L., \& Batalla, J. J. (2008). Los números ocultos del Códice Mendoza y la Matrícula de Tributos/The hidden numbers of the Codex Mendoza and the Matrícula de Tributos. Revista Española de Antropología Americana, 38(2), 199-206. Disponível em: https://revistas.ucm.es/index.php/REAA/article/view/REAA0808220199A

Ronco, A. P., \& Martorelli, B. C. P. (2008). A Educação através dos Códices Astecas. Semioses, 2(1), 118-130. Disponível em: https://silo.tips/download/a-educaao-atraves-dos-codices-astecas

Rosado, J. J. B. (2007a). The Scribes who Painted the Matrícula de Tributos and the Codex Mendoza. Ancient Mesoamerica, 18(1), 31-51. https://doi.org/10.1017/S0956536107000077

Rosado, J. J. B. (2007b). "Matrícula de tributos" y "Códice Mendoza": la autoría de un mismo "maestro de pintores" para los folios 6-R a 11-V del primero y la totalidad del segundo. In: Anales del Museo de América. Subdirección General de Documentación y Publicaciones, 9-20. Disponível em: https://dialnet.unirioja.es/servlet/articulo?c odigo $=2570721$

Salazar, P. A., \& López, O. R. (2015). La luz en la cultura Azteca-Mexica. Ingenierias, 18(8). Disponível em: https:// dialnet.unirioja.es/servlet/articulo?codigo $=5247957$

Santos, A. M. (2013). A diferença na reescrita da violência colonial. Interdisciplinar-Revista de Estudos em Lingua e Literatura, 13, 73-80. Disponível em: https://seer.ufs.br/index.php/interdisciplinar/article/view/1164

Silva, A. C. R. (2010). Metodologia da Pesquisa aplicada à Contabilidade, 3a ed. São Paulo: Atlas.

Smith, M. E. (2015). The Aztec Empire. In A. Monson \& W. Scheidel (eds.). Fiscal regimes and the political economy of premodern states. Cambridge University Press.

Smith, M. E., \& Hicks, F. (2016). Inequality and Social Class in Aztec Society (pp. 423-436). The Oxford Handbook of the Aztecs.

Soustelle, J. (2002). A civilização asteca. Rio de Janeiro: Zahar.

Tarlton Law Library (2018, novembro). Aztec and Maya Law. Aztec Commercial and Tax Law. Recuperado de: http ://tarlton.law.utexas.edu/aztec-and-maya-law/aztec-commercial-and-tax-law.

Tello, F. M. (2012). El desastre de la documentación indígena durante la invasión-conquista española en Mesoamérica. LIS Critique (Library and Information Science Critique):Journal of the Sciences of Information Recorded in Documents (Critica Bibliotecológica: Revista de las Ciencias de la Información Documental), 4(2), 20-32. Disponível em: http://eprints.rclis.org/16985/ 
Universidad Nacional Autónoma de México (UNAM). (2019, junho). Motecubzoma ante la conquista. Recuperado de: http://www.historicas.unam.mx/publicaciones/publicadigital/libros/historias_conquista/438a_04_04_M otecuhzomaConquista.pdf

Valle, P. (2017). La Lámina VIII del Códice de Tlatelolco. Una propuesta de lectura. Dimensión Antropológica, 2, 7-19. Disponível em: https://www.dimensionantropologica.inah.gob.mx/?p=1556

\section{Notas}

* Artículo de revisión.

\section{Licencia Creative Commons CC BY 4.0}

Para citar este artigo: Schmidt, P., \& Santos, J. L. (2020). Estudo da contabilização dos tributos astecas sob a ótica da nova história da contabilidade. Cuadernos de Contabilidad, 21. https://doi.org/10.11144/Javeri ana.cc21.ecta 